\title{
Prey landscapes help identify potential foraging habitats for leatherback turtles in the NE Atlantic
}

\author{
Matthew J. Witt ${ }^{1}$, Annette C. Broderick ${ }^{1}$, David J. Johns ${ }^{2}$, Corinne Martin ${ }^{3}$, \\ Rod Penrose ${ }^{4}$, Marinus S. Hoogmoed ${ }^{5}$, Brendan J. Godley ${ }^{1, *}$
}

\author{
${ }^{1}$ Marine Turtle Research Group, Centre for Ecology and Conservation, University of Exeter, Cornwall Campus, \\ Penryn TR10 9EZ, UK \\ ${ }^{2}$ Sir Alister Hardy Foundation for Ocean Science, The Laboratory, Citadel Hill, Plymouth PL1 2PB, UK \\ ${ }^{3}$ Department of Geographical and Life Sciences, Canterbury Christ Church University, Canterbury CT1 1QU, UK \\ ${ }^{4}$ Marine Environmental Monitoring, Penwalk, Llechryd, Cardigan, Ceredigion SA43 2PS, UK \\ ${ }^{5}$ Museu Paraense Emilio Goeldi/CZO/Herpetologia, Caixa Postal 399, CEP 66017-970 Belém, PA, Brasil
}

\begin{abstract}
Identifying key marine megavertebrate habitats has become ever more important as concern increases regarding global fisheries bycatch and accelerated climate change. This will be aided by a greater understanding of the patterns and processes determining the spatiotemporal distribution of species of conservation concern. We identify probable foraging grounds for leatherback turtles in the NE Atlantic using monthly landscapes of gelatinous organism distribution constructed from Continuous Plankton Recorder Survey data. Using sightings data ( $\mathrm{n}=2013$ records, 1954 to 2003) from 9 countries (UK, Ireland, France, Belgium, The Netherlands, Denmark, Germany, Norway and Sweden), we show sea surface temperatures of approximately 10 to $12^{\circ} \mathrm{C}$ most likely indicate the lower thermal threshold for accessible habitats during seasonal foraging migrations to high latitudes. Integrating maps of gelatinous plankton as a possible indicator of prey distribution with thermal tolerance parameters demonstrates the dynamic (spatial and temporal) nature of NE Atlantic foraging habitats. We highlight the importance of body size-related thermal constraints in structuring leatherback foraging populations and demonstrate a latitudinal gradient in body size (Bergmann's rule) where smaller animals are excluded from higher latitude foraging areas. We highlight the marine area of the European continental shelf edge as being both thermally accessible and prey rich, and therefore potentially supporting appreciable densities of foraging leatherbacks, with some suitable areas not yet extensively surveyed.
\end{abstract}

KEY WORDS: Leatherback turtle · Dermochelys coriacea · Bergmann's rule · Gelatinous prey · Climate change $\cdot$ Habitat preference $\cdot$ Jellyfish $\cdot$ Niche

\section{INTRODUCTION}

Identifying marine predator foraging habitats requires an understanding of the spatial and temporal interactions of the species-specific thermal niche and coincident prey availability. Movement studies using electronic tagging have offered significant insights into the selected habitats of fish (Sims et al. 2003, Block et al. 2005), reptiles (James et al. 2005a, Eckert 2006) and birds (Croxall et al. 2005). Assessing predator distribution with respect to the attributes of the environment encountered (e.g. water temperature and prey distribution) should assist in making predictions on the location of important habitats and aid an understanding of why particular habitats are chosen over others (Sims et al. 2006). On fine spatial scales advances have 
been made in enumerating prey, including jellyfish (Brierley et al. 2005) and copepod abundance (Baumgartner et al. 2003). At the scale of ocean basins, data on prey distribution remains limited and analyses of large-scale movements of marine predators with respect to their prey has mostly been restricted to the use of satellite-derived chlorophyll a (Pinaud \& Weimerskirch 2005, Hawkes et al. 2006). For large planktivores, such as the basking shark Cetorhinus maximus, spatial and temporal prey distributions have been constructed using landscapes of calanoid copepods as gathered by the Continuous Plankton Recorder (CPR) Survey (Sims et al. 2006).

Leatherback turtles Dermochelys coriacea exhibit the widest spatial distribution of any reptile, moving through equatorial, tropical and temperate waters. The seasonal presence of leatherback turtles in midlatitude North Atlantic habitats has been previously recorded (Bleakney 1965, Brongersma 1972, Godley et al. 1998). More recently migratory movements into mid-latitude habitats have been demonstrated with satellite tracking (Ferraroli et al. 2004, Hays et al. 2004, James et al. 2005a, Eckert 2006). The occurrence of leatherback turtles in habitats with sea temperatures that induce lethargy in hard-shelled species (Davenport 1997) supports the premise that leatherbacks have an endothermic capacity, thus remaining active in cool prey-rich waters (Davenport 1998, McMahon \& Hays in press). Female leatherbacks foraging in northwest Atlantic waters $\left(15\right.$ to $\left.16.7^{\circ} \mathrm{C}\right)$ have been shown to support core body temperatures $8.2 \pm 2.4^{\circ} \mathrm{C}($ mean $\pm \mathrm{SD})$ above ambient sea temperature (James \& Mrosovsky 2004). This endothermy is thought to be achieved through their considerable body mass (gigantothermy; Paladino et al. 1990) and physiological adaptations including counter-current vasculature in the flippers (Greer et al. 1973), insulating subcutaneous lipid layers (Frair et al. 1972, Davenport et al. 1990) and variable lipid composition and distribution (Davenport et al. 1990). The independence of leatherback muscle metabolism to temperatures between 5 and $38^{\circ} \mathrm{C}$ (Penick et al. 1998) may also favour prolonged occupation of mid-latitude habitats. Leatherback turtles primarily feed on gelatinous organisms such as coelenterates (class Scyphozoa), including Aurelia, Chrysaora, Cyanea and Rhizostoma (Bleakney 1965, Brongersma 1972, Davenport 1998). Pelagic tunicates (Thaliacea) such as pyrosomas and salps (Davenport \& Balazs 1991) and other coelenterates (class Siphonophora) have also been identified as dietary items (Den Hartog \& Van Nierop 1984).

The presence of gelatinous organisms (i.e. coelenterates, siphonophores and thaliaceans) in the Central North Atlantic and North Sea has been recorded by the CPR Survey for more than 50 years (Richardson et al. 2006). CPR data have been used to investigate a wide range of biological phenomena, including plankton assemblages (Beaugrand et al. 2002) and phenology (Edwards \& Richardson 2004), predator foraging ecology (Sims et al. 2006), and invasive species monitoring (Johns et al. 2005). Here we analyse records of sightings, strandings and captures of leatherback turtles and investigate the seasonality and thermal ecology of this species in the NE Atlantic with respect to a novel landscape of gelatinous organism distribution constructed from the CPR Survey. Augmenting coastal observation data with published satellite telemetry studies enables patterns of leatherback distribution in both the neritic and pelagic realms to be considered.

\section{METHODS}

Sightings, strandings and captures. Records of sightings, strandings and captures of leatherback turtles occurring in UK waters (1954 to 2003, $\mathrm{n}=457$ ) were taken from the TURTLE database (available at: www.strandings.com/Wales.html), a repository of marine turtle records operated by Marine Environmental Monitoring. Records of leatherback turtles occurring in French Atlantic waters (1979 to 2003, n = 1176) were obtained from published literature (Duguy 1986a,b, 1988a,b, 1989, 1990, 1992, 1993, 1994, 1995, 1996, 2004, Duguy \& Duron 1982, 1983, 1985, Duguy et al. 1980, 1997a,b, 1999, 2000, 2001，2002，2003). Records for France prior to $1971(n=15)$ were obtained from Brongersma (1972). Records from the TURTLE database for Ireland (1957 to 2003, n = 343 in total) were supplemented by data from G. L. King (pers. comm.). Records taken from G. L. King (pers. comm.) for 1972 to $1999(n=260)$ were accompanied by geographic descriptions. These descriptions were identified on marine navigation charts and assigned coordinates (longitude, latitude) with a $30 \mathrm{~km}$ spatial resolution. Records of leatherback turtles $(n=22)$ occurring on the coasts of Belgium, The Netherlands, Denmark, Germany, Norway and Sweden were collected by M. S. Hoogmoed $(\mathrm{n}=19)$ and taken from Brongersma (1972) $(\mathrm{n}=3)$.

Data were subject to rigorous scrutiny and filtering. Records including multiple individuals were entered into the database as a single record, as were those occurring on the same day in close geographic proximity $(<30 \mathrm{~km})$. Those records not describing the status of turtles (i.e. dead or alive) were not used. Records providing only an approximate month or season of sighting were excluded. Data including approximations of body size, and one record of unrealistic large body size, were withheld from statistical analysis involving morphometric data. Tail length is an insufficient indi- 
cator of sex for juvenile leatherback turtles less than $100 \mathrm{~cm}$ straight carapace length (SCL); therefore, sexing information within records of less than this size was removed.

Sea surface temperature. Sea surface temperature was determined for records of leatherback turtles from the monthly $1^{\circ}$ spatial resolution Hadley Ice and Sea Surface Temperature dataset (Rayner et al. 2003). Sea surface temperature for each record was taken to be the unaltered value of the pixel encompassing the geographic coordinates for the year and month of each record.

Gelatinous organism distribution fields. Gelatinous organism distribution fields were prepared from plankton data collected by the Continuous Plankton Recorder (CPR) survey operated by the Sir Alister Hardy Foundation for Ocean Science (SAHFOS); see Richardson et al. (2006) for a description of equipment and techniques. Monthly distribution fields were constructed from $50 \mathrm{yr}$ of data (1954 to 2003) and represent the near-surface distribution $(<9 \mathrm{~m}$ depth) of coelenterates (CPR code \#451), siphonophores (CPR code \#452) and Thaliacea (Salpidae and Doliolidae, CPR code \#469); see Appendix 1 for monthly sampling locations. The abundance of siphonophores and Thaliacea per sample was counted, whereas for coelenterate tissue only 'presence' was recorded due to these organisms being heavily damaged during sampling. To integrate these groups (coelenterates, siphonophores and Thaliacea) and their differing count scales we formed a binary response (present or absent) for gelatinous zooplankton for each CPR sample. A CPR sample was considered 'present' for gelatinous organisms when any one or more of the categories had a positive count or recorded as 'present'. CPR data was then partitioned into months. Inverse distance-squared interpolation (Beaugrand et al. 2003) was used to form spatial grids (50 km spatial resolution) of gelatinous organism distribution from these monthly subsets. A moving search window $(150 \mathrm{~km}$ radius) was used at each grid intersection to select appropriate CPR records for interpolation. This interpolation procedure weighted each identified CPR sample based on its distance from the search window origin; samples nearer the origin had greater influence on the interpolation result than those further from the origin (Fortin \& Dale 2005). The interpolation procedure produced a final result that represented the proportion of records positive for gelatinous organisms within the search radius. When the search window failed to identify CPR records for interpolation the grid intersection was identified as data deficient. In contrast, when the interpolation procedure identified CPR samples and calculated an overall absence of gelatinous organisms the grid intersection was assigned as absent for gelati- nous organisms. A 2-dimensional non-linear median filtering routine $(3 \times 3$ pixel window) was applied to each month to smooth noisy pixels while maintaining dominant spatial patterns. Contouring procedures were then used to display monthly data. CPR data are recorded during both day and night; as such, the gelatinous organism distribution fields represent an integrated signal of plankton that undergo diel vertical migration (Hays 2003). To ascertain the possible effects and biases introduced from the use of 'presence' mapping we compared the seasonal long-term mean distribution and abundance patterns of siphonophores (CPR code \#452) (1954-2003) using both abundance and 'presence' scales; see Appendix 2 for images. A visual comparison of this imagery demonstrates the validity of relative abundance derived from 'presence' data to portray information on the differences in patterns of abundance among and within seasons.

\section{RESULTS}

\section{Dataset summary}

For the period 1954 to 2003, 1455 sightings, 411 strandings and 147 captures were identified within the spatial area 43 to $70^{\circ} \mathrm{N}, 15^{\circ} \mathrm{W}$ to $21^{\circ} \mathrm{E}$. Of these combined records ( $\mathrm{n}=2013), 1530$ were of leatherback turtles recorded alive ( $76 \%$ of all records) and 483 recorded dead ( $24 \%$ of all records). Sex was determined from 224 records. Near equal numbers of males $(\mathrm{n}=112,46 \%)$ and females $(\mathrm{n}=122,54 \%)$ were recorded.

\section{Spatial distribution and temperature}

The distribution of records of living leatherback turtles (sightings $\mathrm{n}=1420$, strandings $\mathrm{n}=10$, captures $\mathrm{n}=$ 100) displayed a latitudinally broadening pattern from late spring to early autumn (May to October; Fig. 1a). During the winter and spring the number and spatial distribution of records contracts. Sea surface temperature (SST) was determined for 1984 (99\%) turtle records (Fig. 1b). SST could not be reliably determined for 29 records due to the low resolution of their geographic coordinates. Minimum and maximum SST obtained were 4.7 and $22.0^{\circ} \mathrm{C}$ respectively. SST estimated for records of living $(\mathrm{n}=1512)$ and dead $(\mathrm{n}=$ 472) turtles differed significantly (Fig. 1b, Wilcoxon ranksum test, ranksum $=305364, \mathrm{p}<0.001$, alive median $18.6^{\circ} \mathrm{C}$, dead median $15.1^{\circ} \mathrm{C}$ ). When considering only records of living leatherback turtles (Fig. 1b, open bars), very few records have mean monthly SSTs less than $12^{\circ} \mathrm{C}$ and only in exceptional cases do records 

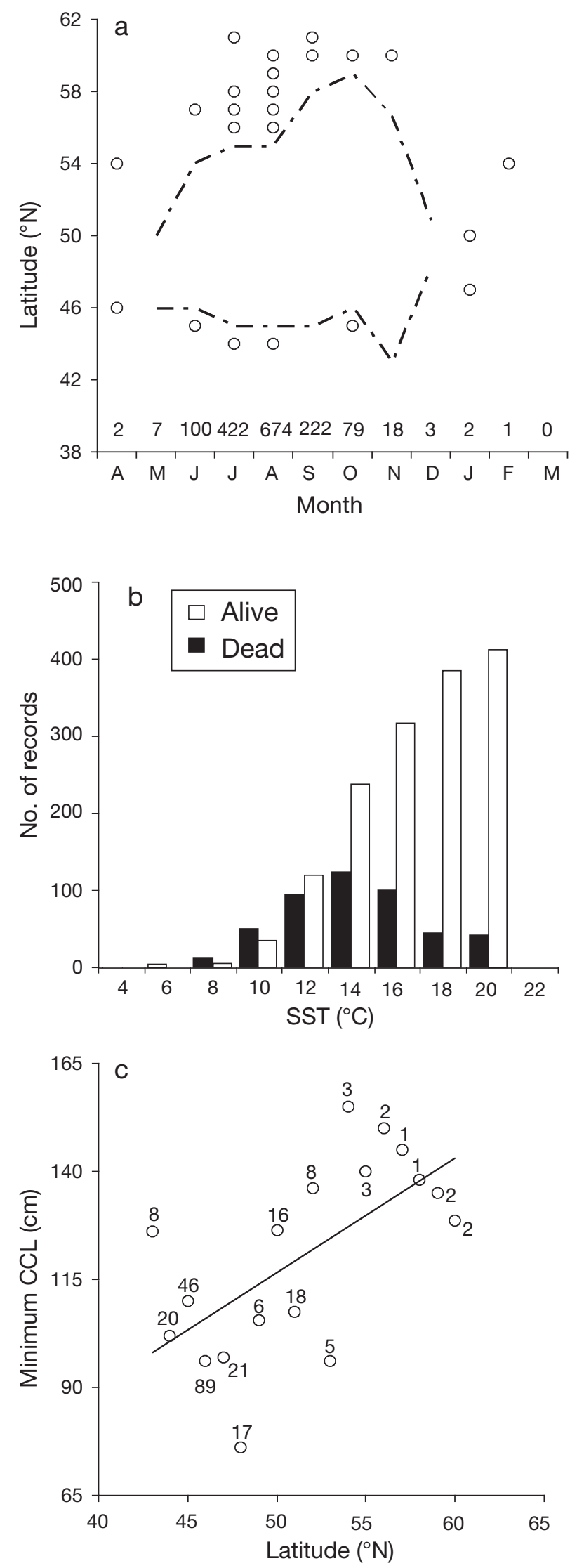

have SSTs below $10^{\circ} \mathrm{C}$. We propose that surface water temperatures of approximately 10 to $12^{\circ} \mathrm{C}$ are indicative of the lower thermal threshold to prolonged seasonal occupation (weeks to months).

\section{Body size}

Measurement of curved carapace length (CCL) and/or SCL, the most commonly used metrics of body size in marine turtles, were obtained from 268 records. CCL was calculated for records containing only SCL $(\mathrm{n}=30)$ using the relationship $(y=1.0352 x+1.9365$, $\left.\mathrm{R}^{2}=0.94, F_{1,9}=126.7, \mathrm{p}<0.001\right)$ derived from 10 records containing both measures. Six of these records were collected during post-mortem in the UK. CCL ranged between 76 and $208 \mathrm{~cm}(\mathrm{n}=268$, mean $\pm \mathrm{SD}$ $144 \pm 18.2 \mathrm{~cm})$. Minimum CCL increased with increasing latitude (Fig. $1 \mathrm{c}, \mathrm{R}^{2}=0.4, F_{1,17}=10.4, \mathrm{p}=0.005$ ). Length for males $(\mathrm{n}=87$, mean $\pm \mathrm{SD} 150 \pm 17 \mathrm{~cm})$ and females $(\mathrm{n}=94$, mean \pm SD $145 \pm 15 \mathrm{~cm}$ ) were not statistically different (Wilcoxon rank sum test, rank sum $=8524, \mathrm{p}>0.05)$.

\section{Gelatinous organism distribution inferred from CPR data for the NE Atlantic}

Fig. 2 shows the spatial and temporal distribution of live leatherback turtles occurring between May and October (1954 to 2003) upon monthly long-term mean gelatinous organism distribution (1954 to 2003) and monthly long-term mean position of sea surface temperature isotherms $\left(10^{\circ} \mathrm{C}\right.$ and $\left.12^{\circ} \mathrm{C}\right)$ for the same period; see Appendix 3 (www.int-res.com/articles/ suppl/m337p231_app3.html) for a year-round monthly animation. Records of leatherback turtles predominantly occur on coasts facing the NE Atlantic. In late spring and early summer (June and July) there is a pulse of gelatinous organisms along the continental shelf break and in the area of the Rockall Bank. In late summer and early autumn (August to September)

Fig. 1. Dermochelys coriacea. (a) Spatial and temporal distribution of reports of live leatherback turtles (1954-2003) on the European continental shelf. Dashed lines: 5th and 95th percentiles of this monthly spatial distribution; (O) records outside the defined range. Records between January and April are outside of the core seasonal distribution and represent 5 records in 50 years; the individual latitudes of these records are shown. Number of records for each month is shown above $x$-axis. (b) Sea surface temperature for records of leatherback turtles (alive $\mathrm{n}=1514$, dead $\mathrm{n}=474$ ). (c) Minimum curved carapace length, CCL $(\mathrm{cm})$ observed at each degree of latitude (O) from records with carapace measurements $(\mathrm{n}=268)$. Solid line indicates regression $\left(\mathrm{R}^{2}=0.4, F_{1,17}=10.4, \mathrm{p}<0.001\right)$ 

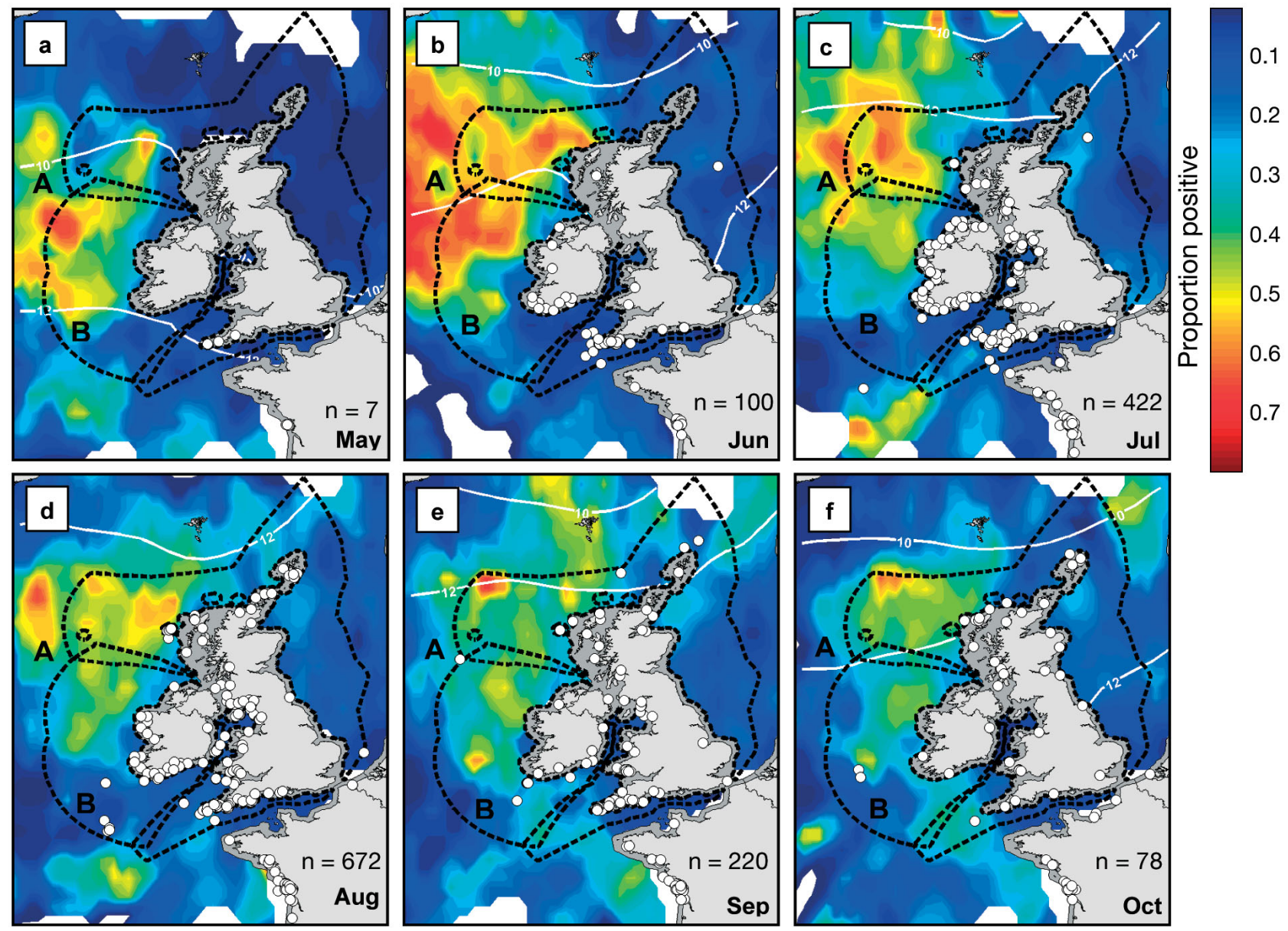

Fig. 2. Leatherback turtles Dermochelys coriacea and gelatinous organisms in the NE Atlantic. Long-term monthly mean (1954-2003) gelatinous organism distribution with records of live leatherback turtles $(\bigcirc)$ for May to October (1954-2003). n: number of records within each monthly image. White zones: CPR data deficient regions. Solid white lines: long-term monthly mean position of the 10 and $12^{\circ} \mathrm{C}$ sea surface isotherms (Hadley ISST, 1954-2003). A: Rockall Bank. B: Porcupine Bank and Porcupine Bight. Dashed black lines: UK declared fishing zone and the Exclusive Economic Zone (EEZ) of Ireland (overlap of UK Fishing Zone and Irish EEZ is disputed territory). Grey coastal zone: territorial waters (12 nautical miles from coastal baseline). Proportion positive: proportion of CPR samples at each location positive for gelatinous organisms

gelatinous organisms become dispersed across the European continental shelf.

Basin scale maps of seasonal long-term mean gelatinous organism distribution (Fig. 3) highlight a spatial association of satellite-tracked leatherback turtles (Fig. 3: box A, Ferraroli et al. 2004; box B, Hays et al. 2004) with regions of appreciable gelatinous organism relative abundance. Boxes circumscribe the minimum and maximum spatial extents of movement within the extents of the displayed images. Ferraroli et al. (2004) and Hays et al. (2004) do not provide seasonal timings for their satellite-tracked leatherback turtles, so these occupation boxes have been applied to both seasons, although occupation is most likely to have occurred during late summer and autumn. Gelatinous organism distribution fields highlight the European continental shelf-break and the Rockall Bank (Fig. 3: box C) as regions that support appreciable aggregations of gelatinous organisms and are within the proposed thermal niche for leatherback turtles.

To ascertain the relative importance of the spatial regions circumscribed by boxes $\mathrm{A}$ and $\mathrm{B}$ we used a randomised block re-sampling bootstrap procedure on each seasonal image (available spatial range for bootstrapping: $65^{\circ} \mathrm{W}$ to $4^{\circ} \mathrm{E}, 36^{\circ}$ to $64^{\circ} \mathrm{N}$ ). We chose this procedure as it retains the spatial correlation structure inherent in many environmental datasets. Each resampling block took the dimensions of box A or box B (5000 iterations box ${ }^{-1}$ season $^{-1}$ ). Blocks were randomly positioned on the seasonal image following random rotation (angle randomly selected from 0 to $360^{\circ}$ ). Mean gelatinous organism relative abundance circumscribed by the re-sampling block was then calculated. Results from bootstrap procedures are shown by the 

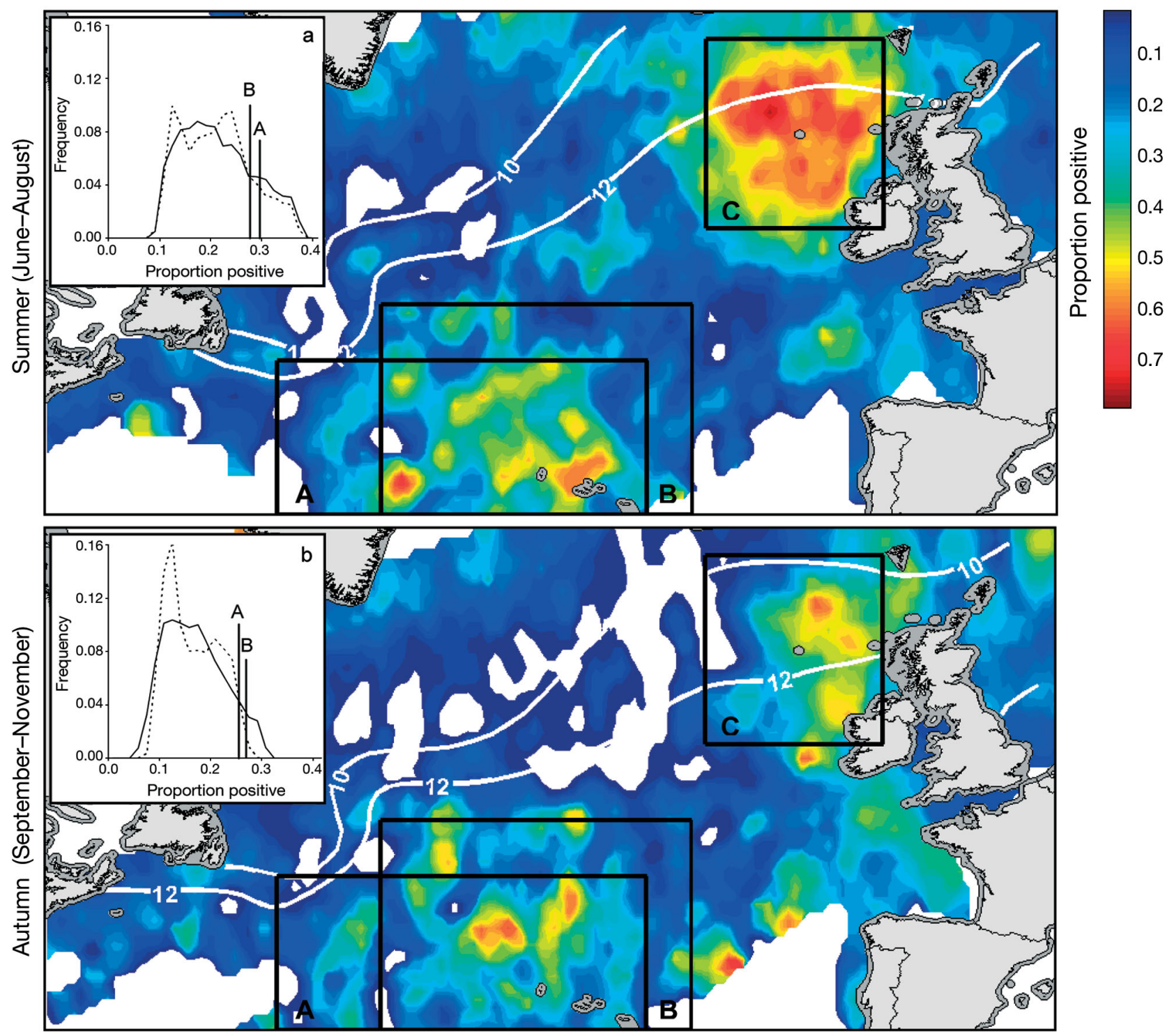

Fig. 3. Gelatinous organisms in the North Atlantic. Long-term seasonal mean (1954-2003) gelatinous organism distribution for (a) summer and (b) autumn. White zones: CPR data deficient regions. Solid white lines: long-term seasonal mean position of the 10 and $12^{\circ} \mathrm{C}$ sea surface isotherms (Hadley ISST, 1954-2003). Boxes A and B describe leatherback turtle occupation zones recorded from satellite tracking by Ferraroli et al. (2004) (2 turtles), and Hays et al. (2004) (5 turtles), respectively, and circumscribe the minimum and maximum spatial extents of movement within the displayed images. Box C highlights a region that may support appreciable numbers of foraging individuals during thermally accessible periods. Insets: frequency distributions of mean gelatinous organism relative abundance calculated from randomised block re-sampling (bootstrapping) using dimensions of box A (solid line) and box B (dotted line) for (a) summer and (b) autumn. Vertical lines: mean gelatinous organism relative abundance calculated for box A and B prior to the bootstrapping routine

inset frequency distributions (Fig. 3a,b). Mean gelatinous organism relative abundances experienced by box A and B during summer were at the 89th and 90th percentiles respectively of their bootstrap distributions. For autumn, boxes A and B were at the 94th and 99th percentiles respectively of their comparative bootstrap distribution. Clearly, leatherback turtles are using habitats that are typically productive for gelatinous organisms.

\section{DISCUSSION}

Records of leatherback turtles on the European continental shelf are mostly confined to NE Atlantic-facing aspects of France, Ireland and the UK. The temporal distribution of records demonstrates a seasonal pattern, increasing during the summer and declining during late autumn and winter. A similar pattern is observed in North Atlantic coastal habitats of the 
United States and Canada (Bleakney 1965, James et al. 2005b). Patterns of seasonal occupation inferred from public sightings records must however be interpreted with caution as they lack correction for spatial and temporal (seasonal) bias in survey effort. Notwithstanding this caveat, the presence of leatherback turtles in neritic environments ( $<200 \mathrm{~m}$ depth) together with recent satellite tracking (Eckert 2006) demonstrates that the NE Atlantic is a seasonally occupied habitat.

The presence of leatherback turtles in the NE Atlantic, taken in the context of measurements of core body temperatures (James \& Mrosovsky 2004), further demonstrates endothermic capacity in this species. Despite thermal inertia, temperature thresholds most likely limit regions that can be occupied for prolonged periods (weeks to months). For adult leatherback turtles we speculate that conditions leading to nearsurface temperatures of approximately 10 to $12^{\circ} \mathrm{C}$ act as a lower threshold to prolonged occupation (weeks to months) although it is clear that they can endure much cooler waters for short periods (James et al. in press). Habitat demarcating isotherms for leatherback turtles have also been outlined by McMahon \& Hays (in press); however, these authors arrive at $15^{\circ} \mathrm{C}$ as being the limiting isotherm based on in situ measurements of sea temperature from telemetered turtles. This difference in habitat demarcating isotherms most likely arises from a spatial and temporal mismatch in the resolution of both sampling techniques and dataproducts. Furthermore, differences in body size and nutritional status are also likely to limit the extent of thermally accessible habitat. In agreement with McMahon \& Hays (in press) we suggest that the waters of the UK most likely represent the northerly limit for the majority of seasonal leatherback foraging migrations under current thermal regimes. While isotherms of surface conditions appear to demarcate seasonal habitats, temperatures of $2.5^{\circ} \mathrm{C}$ experienced at depth when diving from warm surface waters $\left(15.6\right.$ to $\left.19.1^{\circ} \mathrm{C}\right)$ in mid-latitude habitats appear not to influence dive behaviour (James et al. in press).

Morphometric data taken from records of leatherback sightings, strandings and capture suggests that size structuring of individuals occurs in the NE Atlantic. Smaller individuals appear to be excluded from higher latitude cooler water habitats, a pattern most likely driven by gigantothermy. A similar pattern of distribution has been identified within juvenile leatherback turtles in a lower latitudinal range (Eckert 2002). Furthermore, leatherbacks occupying French Atlantic waters are significantly smaller than those occurring at similar latitudes in northwest Atlantic habitats where water temperatures are considerably cooler (James et al. 2007, this volume). Latitudinal clines in body size, as described by Bergmann's rule, have been documented in many terrestrial species (Ashton et al. 2000). Although sightings records do not allow for an examination of individual movement patterns across years, they do indicate that body sizerelated thermal constraints play a role in structuring foraging assemblages. Longer term monitoring (years) of male and female leatherbacks using satellite telemetry, which is currently limited due to constraints of battery life, sensor and device attachment failure, would allow for a detailed examination of the spatial distribution of leatherback turtles in years between breeding. In these years, individuals may find it possible to increase their northward extent as a result of increased body fat with concomitant increase in insulation and reduction of surface area to volume ratio.

The presence of leatherback turtles in neritic habitats most likely highlights the effects of the predominant wind driven surface currents on the European continental shelf that aggregate gelatinous organisms. Surface currents can aggregate forage along coastal margins (Graham et al. 2001) and within embayments (Houghton et al. in press). The recorded behaviour of leatherback turtles in neritic (Eckert et al. 1989) and pelagic habitats (Hays et al. 2004, James et al. 2005a) suggest diving plays an important function in enhancing prey capture especially when epipelagic availability of gelatinous forage is poor (Davenport 1988). Leatherbacks exhibit a diel periodicity in diving behaviour, inhabiting shallower habitats by night and deeper habitats by day, presumably in response to vertical tracking of their diel migrating prey (Eckert et al. 1989). Although leatherback turtle behaviour can be punctuated by deep dives this species remains a predominantly epipelagic (0 to $200 \mathrm{~m}$ depth) forager (Hays et al. 2004). Such behaviour supports the usefulness of CPR data that show gelatinous organism distribution in upper-surface layers.

Gelatinous organism landscapes demonstrate the importance of topographic features and regional hydrography for aggregating prey or enhancing localised productivity (Graham et al. 2001). The continental shelf-break, including the Porcupine Bank and Porcupine Bight and the Rockall Bank and Trough, is spatially coincident with appreciable aggregation of gelatinous organisms and as such represents habitats that require boat-based or aerial investigation of leatherback distribution. The occurrence of previously undescribed gelatinous organism rich habitats within jurisdictional waters of European Union member states highlights the necessity to enumerate the presence of foraging leatherbacks. Smaller oceanographic features that aggregate gelatinous organisms, such as Langmuir circulation cells (Graham et al. 2001), cannot be adequately resolved by the CPR survey but are likely 
to play a role in generating profitable, but short lived, prey patches. If predictions are confirmed and densities are sufficiently high it would be appropriate to monitor fisheries in these regions for bycatch and adopt appropriate mitigating techniques. Maps of gelatinous organism distribution provide an important synoptic view of potential prey availability and allow for an assessment of the interactions between the sometimes spatially conflicting thermal and prey niches. Prey fields indicate that the central North Atlantic supports several appreciable aggregations of gelatinous organisms. It is likely that these aggregations reflect the dynamic nature of the North Atlantic gyre. This region supports the separation of eddies that can enhance localised productivity (divergent eddies) or aggregate prey (convergent eddies). Leatherback habitat utilisation from satellite tracking (Ferraroli et al. 2004, Hays et al. 2004) suggests movements are most likely directed to regions that show seasonally persistent densities of prey over decadal timescales. Identifying these regions as likely foraging grounds provides important direction for conservation efforts, particularly as they exist within areas where potential conflicting fishing effort is considerable (Lewison et al. 2004).

\section{Evaluating the usefulness of presence data from the CPR Survey}

Mapping of abundance data for CPR taxa has become increasingly useful to visualise spatial and temporal distribution patterns of plankton (see CPR Survey Team 2004). Semi-quantitative data recorded by the CPR survey such as the phytoplankton colour index (PCI), an index of CPR sample greenness (Richardson et al. 2006), has similarly been mapped (Vezzulli \& Reid 2003) and shows the seasonal progression of phytoplankton in the North Sea. Mapping of 'presence' data involving interpolation techniques to derive relative abundance has not been previously attempted. However, seasonal analyses of a phytoplankton taxon (Phaeocystis) recorded as present/ absent has been achieved (Gieskes et al. in press) and Attrill et al. (in press) have recently described spatial patterns in coelenterate data for the North Sea from the CPR survey. The comparison of 'presence' mapping for siphonophores (see Appendix 2) suggests our technique resolves patterns equivalent to those produced using abundance counts; some information, especially patchy ephemeral blooms, is undoubtedly lost when using a coarse presence/ absence scale. We feel, however, our synoptic approach does not overinterpret the data. The demonstrated mapping technique is an important step towards developing a trophic-appropriate prey proxy for leatherback turtles and enables validation to other biological datasets on gelatinous prey productivity.

Two additional caveats must be considered with the use of CPR data in the presented context. Firstly, the spatial coverage of near-shore regions by the CPR survey is comparatively weak due to constraints of operating the CPR from merchant ships of opportunity. Consequently, gelatinous organism distribution is most likely underestimated in these habitats. The second caveat involves the efficiency to which the CPR samples gelatinous zooplankton, which has yet to be rigorously quantified; however, mapping of gelatinous plankton presented here offers a useful first step for validation studies. Sampling of gelatinous organisms by the CPR is most likely biased to small species, smaller individuals of larger conspecifics or body parts of gelatinous prey sought by leatherback turtles. This bias may explain the slight temporal lag between maximum relative abundance of gelatinous organisms observed in June and maximum number of leatherback records in August. However, we are confident that the landscapes of gelatinous organism distribution represent meaningful information on the relative distribution of gelatinous organisms as the functional group upon which leatherbacks forage, and indicate important potential foraging habitats requiring further investigation.

\section{Future scenarios}

For predictions of potential foraging habitats to be robust, it is necessary to understand how the physical environment controls productivity and how energy is transferred up trophic food webs on wide spatial and temporal scales. For example, climatic patterns that operate at basin-scales on an interannual basis, such as the North Atlantic Oscillation, influence gelatinous organism distribution and abundance in neritic environments (Lynam et al. 2004, Attrill et al. in press). On decadal scales the dominant climatic pattern to ensue is both complex and unclear; however, reported warming of the world's ocean (Levitus et al. 2000) and the predicted increase in global mean surface temperature of between $1.4^{\circ} \mathrm{C}$ and $5.8^{\circ} \mathrm{C}$ for the period 1990 to 2100 , (IPCC 2001) is likely to have a considerable effect. In NE Atlantic ecosystems the response of plankton to increasing sea temperature has differed regionally. Warming of cooler regions has led to increased plankton abundance, whereas further warming of previously warmer regions has led to a decrease (Richardson \& Schoeman 2004). For gelatinous organisms in temperate neritic habitats, warm temperatures mostly induce large numbers of individuals and increase rates 
of reproduction (Purcell 2005); whether such responses extend to pelagic environments is unknown. The influence of changing zooplankton prey for gelatinous organism distribution is therefore likely to be significant and complex to predict. For leatherback turtles, increasing sea surface temperature may expand foraging areas (McMahon \& Hays in press) through northward range extension into new foraging habitats of high temperate latitudes that are currently inaccessible but prey rich under current climatic and oceanographic conditions. Contrary to predictions of ocean warming, a weakening global thermohaline circulation may result in a subsequent failure to transfer heat from the tropics to more northern latitudes (IPCC 2001). Decreasing sea temperatures would lead to a retreat in leatherback foraging populations from their current northern limits. It is clear therefore that making even qualitative predictions of the likely impact of climate change on leatherback turtle distribution, based on data in hand, is a far from trivial task.

Population dynamics of gelatinous zooplankton also appear to be affected by fisheries practices. Extensive overfishing in the Benguela upwelling system has led to a stable state of gelatinous zooplankton dominance over fish (Lynam et al. 2006). Such states suppress fish stocks and lead to altered nutrient cycling regimes, yet they may offer important foraging grounds for leatherback turtles, particularly if they are spatially and temporally coincident with migration routes of zooplanktivores. Such shifts to gelatinous organism dominance in pelagic habitats have been speculated upon (Sommer et al. 2002) but are yet to be described.

We have shown how using a synergistic approach of integrating habitat mapping of environmental temperature and forage distribution with megavertebrate distribution patterns from public sightings and satellite telemetry adds to a greater understanding of how the ocean environment may drive patterns of space use in marine megavertebrates. The presented prey fields contribute to a greater understanding of the distribution of secondary productivity over broad spatial and temporal scales, and provide an important environmental layer on which to interpret the distribution of other facultative and obligate zooplanktivorous species, particularly zooplanktivorous fish. Furthermore, the adopted approach aids the identification of potential habitats for future scientific investigation and for directing conservation effort in both pelagic and neritic habitats.

Acknowledgements. We thank Dr. R. Duguy and G. King for their diligence in collecting data and subsequent publications on marine turtles occurring in French and Irish waters, respectively. TURTLE, operated by Marine Environmental Monitoring, receives financial support from Scottish Natural
Heritage, English Nature, and the Countryside Council for Wales. CPR data was provided under license agreement. SAHFOS is funded by a consortium made up of governmental agencies from Canada, France, Iceland, Ireland, the Netherlands, Portugal, the UK, and the USA that financially supports the CPR survey. This analysis was supported by grants to B.J.G. and A.C.B. from the Natural Environment Research Council (NERC), Darwin Initiative, UK Overseas Territories Environment Programme and the European Social Fund. M.J.W. is funded by a NERC PhD studentship at the Centre for Ecology and Conservation, University of Exeter, Cornwall Campus (Award No. NER/S/A/2004/12980). We thank Michael Coyne, Matthew Godfrey, Lucy Hawkes, Peter Richardson and Janice Blumenthal for comments on earlier versions of this manuscript and G. Hays and 2 anonymous reviewers for constructive criticism that improved this manuscript.

\section{LITERATURE CITED}

Ashton KG, Tracy MC, Queiroz AD (2000) Is Bergmann's rule valid for mammals? Am Nat 156:390-415

Attrill MJ, Wright J, Edwards M (2007) Climate-related increases in jellyfish frequency suggest a more gelatinous future for the North Sea. Limnol Oceanogr 52:480-485

Baumgartner MF, Cole TVN, Campbell RG, Teegarden GJ, Durbin EG (2003) Associations between North Atlantic right whales and their prey, Calanus finmarchicus, over diel and tidal time scales. Mar Ecol Prog Ser 264:155-166

Beaugrand G, Ibañez F, Lindley JA, Philip C, Reid PC (2002) Diversity of calanoid copepods in the North Atlantic and adjacent seas: species associations and biogeography. Mar Ecol Prog Ser 232:179-195

Beaugrand G, Ibañez F, Lindley JA (2003) An overview of statistical methods applied to CPR data. Prog Oceanogr 58:235-262

Bleakney JS (1965) Reports of marine turtles from New England and eastern Canada. Can Field-Nat 120:120-128

Block BA, Teo SL, Walli A, Boustany A and 5 others (2005) Electronic tagging and population structure of Atlantic bluefin tuna. Nature 434:1121-1127

Brierley AS, Boyer DC, Axelsen BE, Lynam CP, Sparks CAJ, Boyer HJ, Gibbons MJ (2005) Towards the acoustic estimation of jellyfish abundance. Mar Ecol Prog Ser 295: 105-111

Brongersma LD (1972) European Atlantic turtles. Zool Verh 121:1-318

CPR Survey Team (2004) Continuous Plankton Records: Plankton Atlas of the North Atlantic Ocean (1958-1999). II. Biogeographical charts. Mar Ecol Prog Ser Suppl: $11-75$

Croxall JP, Silk JR, Phillips RA, Afanasyev V, Briggs DR (2005) Global circumnavigations: tracking year-round range of nonbreeding albatrosses. Science 307:249-250

Davenport J (1988) Do diving leatherbacks pursue glowing jellyfish? Brit Herpetol Soc Bull 24:20-21

Davenport J (1997) Temperature and the life-history strategies of sea turtles. J Therm Biol 22:479-488

Davenport J (1998) Sustaining endothermy on a diet of cold jelly: energetics of the leatherback turtles Dermochelys coriacea. Brit Herpetol Soc Bull 62:4-8

Davenport J, Balazs GH (1991) Fiery bodies — are pyrosomas an important component of the diet of leatherback turtles? Brit Herpetol Soc Bull 37:33-38

Davenport J, Holland DL, East J (1990) Thermal and biochemical characteristics of the lipids of the leatherback turtle Dermochelys coriacea: evidence of endothermy? 
J Mar Biol Assoc UK 70:33-41

Den Hartog JC, Van Nierop MM (1984) A study on the gut contents of 6 leathery turtles Dermochelys coriacea (Linnaeus) (Reptilia: Testudines: Dermochelyidae) from British Waters and The Netherlands. Zool Verh 209:1-31

Duguy R (1986a) Observations de tortues marines sur les côtes de France en 1985. Ann Soc Sci Nat Charente-Marit $7: 543-546$

Duguy R (1986b) Observations de tortues marines sur les côtes de France en 1986. Ann Soc Sci Nat Charente-Marit $7: 641-642$

Duguy R (1988a) Observations de tortues marines sur les côtes de France en 1987. Ann Soc Sci Nat Charente-Marit 7:727-728

Duguy R (1988b) Observations de tortues marines sur les côtes de France (Atlantique et Manche) en 1988. Ann Soc Sci Nat Charente-Marit 7:821-824

Duguy R (1989) Observations de tortues luth sur les côtes de France en 1989. Ann Soc Sci Nat Charente-Marit 7:959-960

Duguy R (1990) Observations de tortues marines en 1990 (Manche et Atlantique). Ann Soc Sci Nat Charente-Marit 7:1053-1057

Duguy R (1992) Observations de tortues marines en 1991 (Atlantique). Ann Soc Sci Nat Charente-Marit 8:35-37

Duguy R (1993) Observations de tortues marines en 1992 (Atlantique). Ann Soc Sci Nat Charente-Marit 8:129-131

Duguy R (1994) Observations de tortues marines en 1993 (Atlantique). Ann Soc Sci Nat Charente-Marit 8:235-238

Duguy R (1995) Observations de tortues marines en 1994 (Atlantique). Ann Soc Sci Nat Charente-Marit 8:403-406

Duguy R (1996) Observations de tortues marines en 1995 (Atlantique). Ann Soc Sci Nat Charente-Marit 8:505-513

Duguy R (2004) Observations de tortues marines en 2003 (côtes Atlantiques). Ann Soc Sci Nat Charente-Marit 9:361-366

Duguy R, Duron M (1982) Observations de tortues luth (Dermochelys coriacea L.) sur les côtes de France en 1981. Ann Soc Sci Nat Charente-Marit 6:1015-1020

Duguy R, Duron M (1983) Observations de tortues luth (Dermochelys coriacea) sur les côtes de France en 1982. Ann Soc Sci Nat Charente-Marit 7:153-157

Duguy R, Duron M (1985) Observations de tortues luth (Dermochelys coriacea) sue les côtes de France en 1984. Ann Soc Sci Nat Charente-Marit 7:381-384

Duguy R, Duron M, Alzieu C (1980) Observations de tortues luth (Dermochelys coriacea L.) dans les pertuis Charentais en 1979. Ann Soc Sci Nat Charente-Marit 6:681-691

Duguy R, Moriniere P, Spano MA (1997a) Observations de tortues marines en 1996 (Atlantique). Ann Soc Sci Nat Charente-Marit 8:625-632

Duguy R, Moriniere P, Meunier A (1997b) Observations de tortues marines en 1997. Ann Soc Sci Nat Charente-Marit 8:761-779

Duguy R, Moriniere P, Meunier A (1999) Observations de tortues marines en 1998 (Atlantique). Ann Soc Sci Nat Charente-Marit 8:911-924

Duguy R, Moriniere P, Meunier A (2000) Observations de tortues marines en 1999. Ann Soc Sci Nat Charente-Marit 8:1025-1034

Duguy R, Moriniere P, Meunier A (2001) Observations tortues marines en 2000 (Atlantique et Manche). Ann Soc Sci Nat Charente-Marit 9:17-25

Duguy R, Moriniere P, Meunier A (2002) Observations de tortues marines en 2001 (Atlantique et Manche). Ann Soc Sci Nat Charente-Marit 9:161-172

Duguy R, Moriniere P, Meunier A (2003) Observations de tortues marines en 2002 (Atlantique et Manche). Ann Soc Sci Nat Charente-Marit 9:265-273
Eckert SA (2002) Distribution of juvenile leatherback sea turtle Dermochelys coriacea sightings. Mar Ecol Prog Ser 230:289-293

Eckert SA (2006) High-use oceanic areas for Atlantic leatherback sea turtles (Dermochelys coriacea) as identified using satellite telemetered location and dive information. Mar Biol 149:1257-1267

Eckert SA, Eckert KL, Ponganis P, Kooyman GL (1989) Diving and foraging behaviour of leatherback sea turtles (Dermochelys coriacea). Can J Zool 67:2834-2840

Edwards M, Richardson AJ (2004) Impact of climate change on marine pelagic phenology and trophic mismatch. Nature 430:881-884

Ferraroli S, Georges JY, Gaspar P, Maho YL (2004) Where leatherback turtles meet fisheries. Nature 429:521-522

Fortin MJ, Dale M (2005) Spatial analysis, a guide for ecologists. Cambridge University Press, Cambridge

Frair W, Ackman RG, Mrosovsky N (1972) Body temperatures of Dermochelys coriacea: warm turtle from cold water. Science 177:791-793

Gieskes WWC, Leterme SC, Peletier H, Edwards M, Reid PC (2007) Phaeocystis colony distribution in the North Atlantic Ocean since 1948, and interpretation of long-term changes in the Phaetocystis hotspot in the North Sea. Biogeochemistry (in press) doi:10.1007/s10533-007-9082-6

Godley BJ, Gaywood MJ, Law RJ, McCarthy CJ and 5 others (1998) Patterns of marine turtle mortality in British Waters (1992-1996) with reference to tissue contaminant levels. J Mar Biol Assoc UK 78:973-984

Graham WM, Pages F, Hamner WM (2001) A physical context for gelatinous zooplankton aggregations: a review. Hydrobiologia 451:199-212

Greer AE, Lazell JD, Wright RD (1973) Anatomical evidence for a counter-current heat exchanger in the leatherback turtle (Dermochelys coriacea). Nature 244:181

Hawkes LA, Broderick AC, Coyne MS, Godfrey MH and 5 others (2006) Phenotypically linked dichotomy in sea turtle foraging requires multiple conservation approaches. Curr Biol 16:990-995

Hays GC (2003) A review of the adaptive significance and ecosytsem consequences of zooplankton diel vertical migrations. Hydrobiologia 503:163-170

Hays GC, Houghton JD, Myers AE (2004) Pan-Atlantic leatherback turtle movements. Nature 429:522

Houghton JDR, Doyle TK, Wilson MW, Davenport J, Hays GC (2006) Jellyfish aggregations and leatherback turtle foraging patterns in a temperate coastal environment. Ecology 87:1967-1972

IPCC (2001) A report of Working Group 1 on the Intergovernmental Panel on Climate Change. Available at: www.grida. no/climate/ipcc_tar/wg1/pdf/WG1_TAR-FRONT.PDF

James MC, Mrosovsky N (2004) Body temperatures of leatherback turtles (Dermochelys coriacea) in temperate waters off Nova Scotia, Canada. Can J Zool 82:1302-1306

James MC, Myers RA, Ottensmeyer CA (2005a) Behaviour of leatherback sea turtles, Dermochelys coriacea, during the migratory cycle. Proc R Soc Ser B 272:1547-1555

James MC, Ottensmeyer CA, Myers RA (2005b) Identification of high-use habitat and threats to leatherback sea turtles in northern waters: new directions for conservation. Ecol Lett 8:195-201

James MC, Davenport J, Hays GC (2006) Expanded thermal niche for a diving vertebrate: a leatherback turtle diving into near-freezing water. J Exp Mar Biol Ecol 335:221-226

James MC, Sherill-Mix, SA, Myers RA (2007). Population characteristics and seasonal migrations of leatherback sea turtles at high latitudes. Mar Ecol Prog Ser 337:245-254 
Johns DG, Edwards M, Greve W, Sjohn AWG (2005) Increasing prevalence of the marine cladoceran Penilia avirostris (Dana, 1852) in the North Sea. Helgol Mar Res 59:214-218

Levitus S, Antonov JI, Boyer TP, Stephens C (2000) Warming of the world ocean. Science 287:2225-2229

Lewison RL, Freeman SA, Crowder LB (2004) Quantifying the effects of fisheries on threatened species: the impact of pelagic longlines on loggerhead and leatherback sea turtles. Ecol Lett 7:221-231

Lynam CP, Hay SJ, Brierley AS (2004) Interannual variability in abundance of North Sea jellyfish and links to the North Atlantic Oscillation. Limnol Oceanogr 49:637-643

Lynam CP, Gibbons MJ, Axelsen BA, Sparks CAJ, Coetzee J, Heywood BG, Brierley AS (2006) Jellyfish overtake fish in a heavily fished ecosystem. Curr Biol 16:492-493

McMahon CR, Hays GC (2006) Thermal niche, large-scale movements and implications of climate change for a critically endangered marine vertebrate. Glob Change Biol 12:1-9

Paladino FV, O'Connor MP, Spotila JR (1990) Metabolism of leatherback turtles, gigantothermy, and thermoregulation of dinosaurs. Nature 344:858-860

Penick DN, Spotila JR, O'Connor MP, Steyermark AC, George RH, Salice CJ, Paladino FV (1998) Thermal independence of muscle tissue metabolism in the leatherback turtle, Dermochelys coriacea. Comp Biochem Physiol A 120:399-403

Pinaud D, Weimerskirch H (2005) Scale-dependent habitat use in a long-ranging central place forager. J Anim Ecol
$74: 852-863$

Purcell JE (2005) Climate effects of formation of jellyfish and ctenophore blooms: a review. J Mar Biol Assoc UK 85: 461-476

Rayner NA, Parker DE, Horton EB, Folland CK, Alexander LV, Rowell DP (2003) Global analyses of sea surface temperature, sea ice and night marine air temperature since the late nineteenth century. J Geophys Res 108:1-29

Richardson AJ, Schoeman DS (2004) Climate impact on plankton ecosystems in the Northeast Atlantic. Science 305:1609-1612

Richardson AJ, Walne AW, John AWG, Jonas TD, Lindley JA, Sims DW, Stevens D, Witt MJ (2006) Using continuous plankton recorder data. Prog Oceanogr 68:27-74

Sims DW, Southall EJ, Richardson AJ, Reid PC, Metcalfe JD (2003) Seasonal movements and behaviour of basking sharks from archival tagging: no evidence of winter hibernation. Mar Ecol Prog Ser 248:187-196

Sims DW, Witt MJ, Richardson AJ, Southall EJ, Metcalfe JD (2006) Encounter success of free-ranging marine predator movements across a dynamic prey landscape. Proc R Soc Ser B 273:1195-1201

Sommer U, Stibor H, Katechakis A, Sommer F, Hansen T (2002) Pelagic food web configurations at different levels of nutrient richness and their implications for the ratio fish production: primary production. Hydrobiologia 484:11-20

Vezzulli L, Reid PC (2003) The CPR survey (1948-1997): a gridded database browser of plankton abundance in the North Sea. Prog Oceanogr 58:327-336 
Appendix 1. Monthly distribution of CPR sampling locations for the NE and central North Atlantic

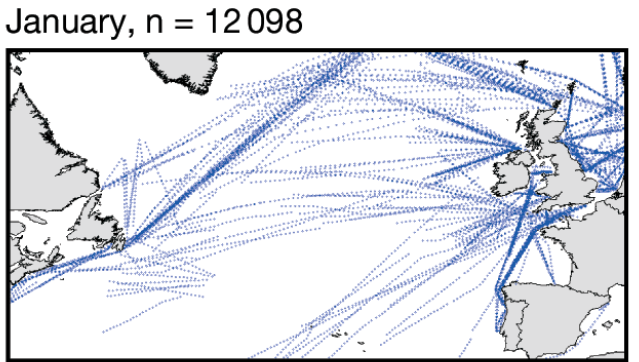

February, $\mathrm{n}=12725$

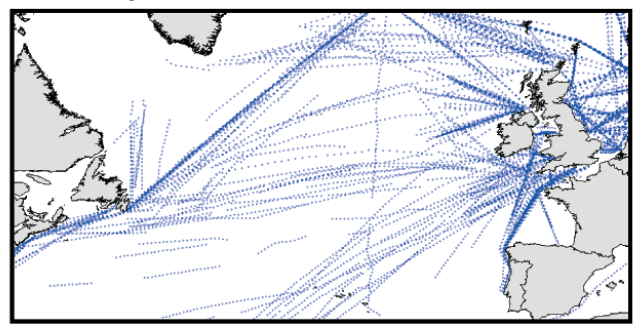

March, $\mathrm{n}=15343$

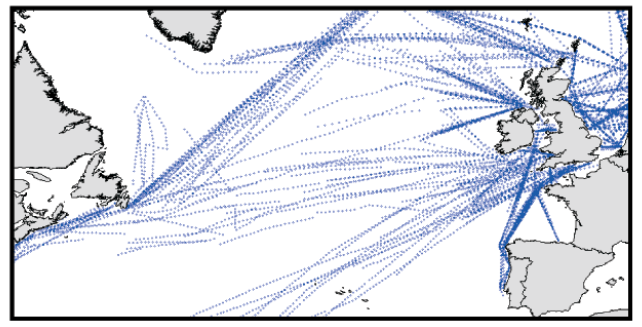

July, $\mathrm{n}=15098$

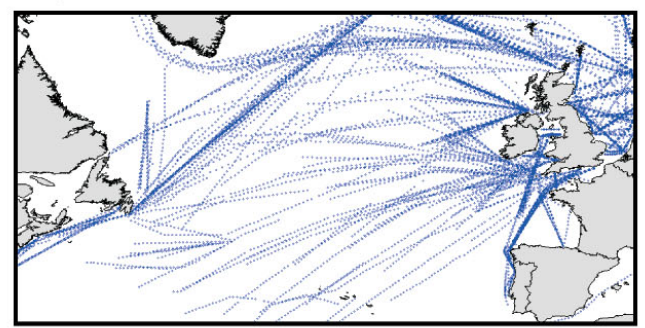

August, $\mathrm{n}=15297$

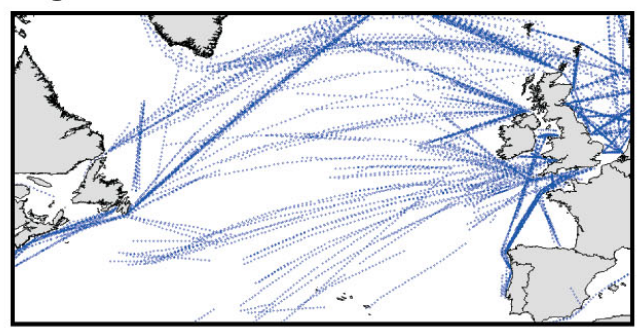

September $\mathrm{n}=14851$

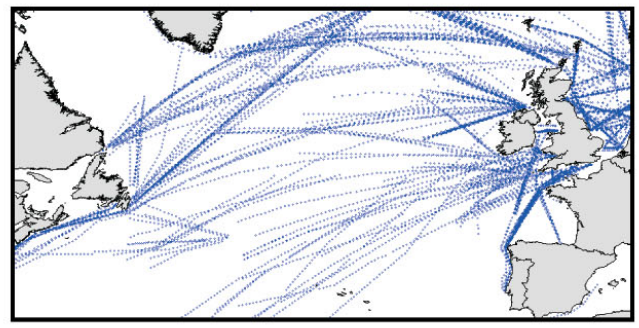

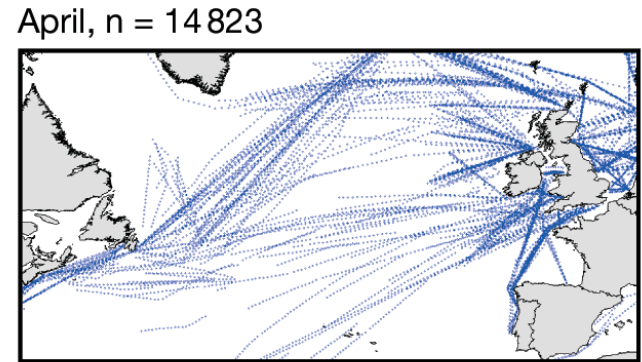

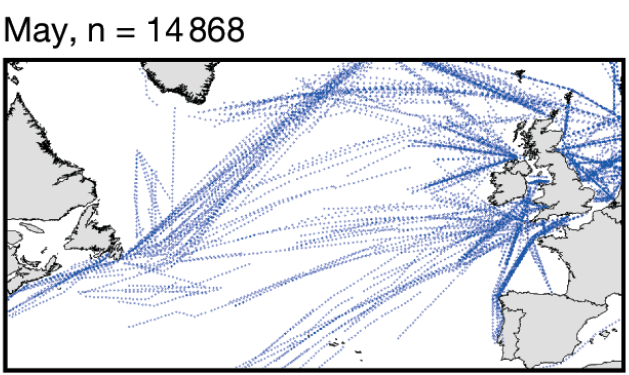

June, $n=14592$

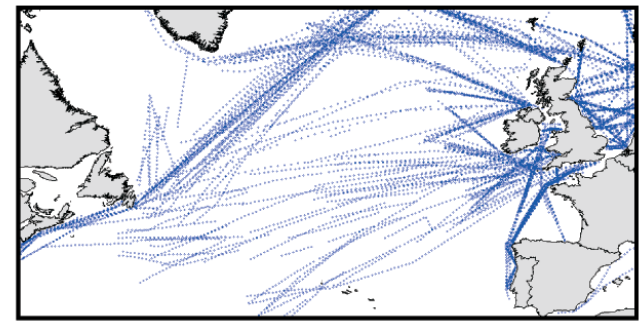

October, $n=14576$

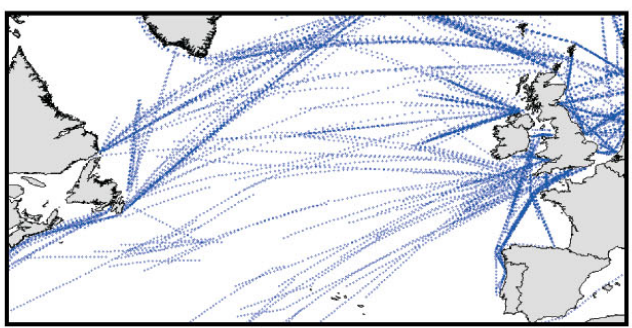

November, $n=13865$

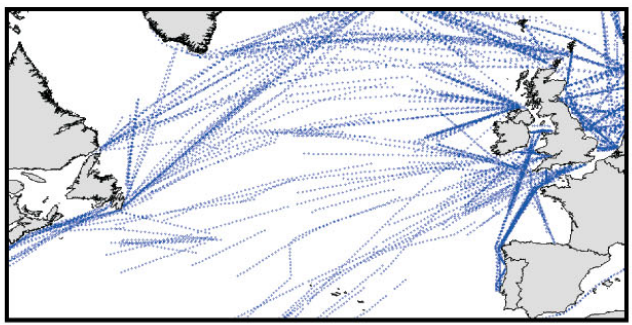

December, $\mathrm{n}=12750$

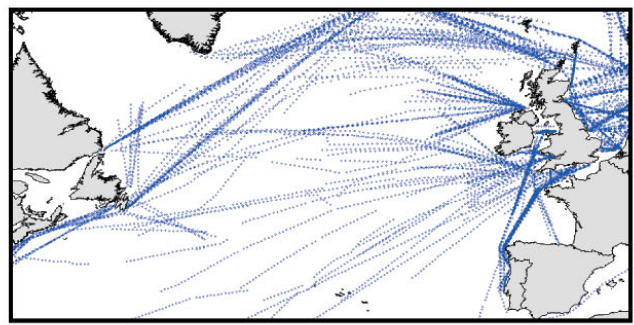


Appendix 2. Seasonal mean long-term distribution of siphonophores recorded by the CPR Survey mapped using (a-d) abundance and $(\mathrm{e}-\mathrm{i})$ proportion of positive records. Note similarity in results for the 2 methods
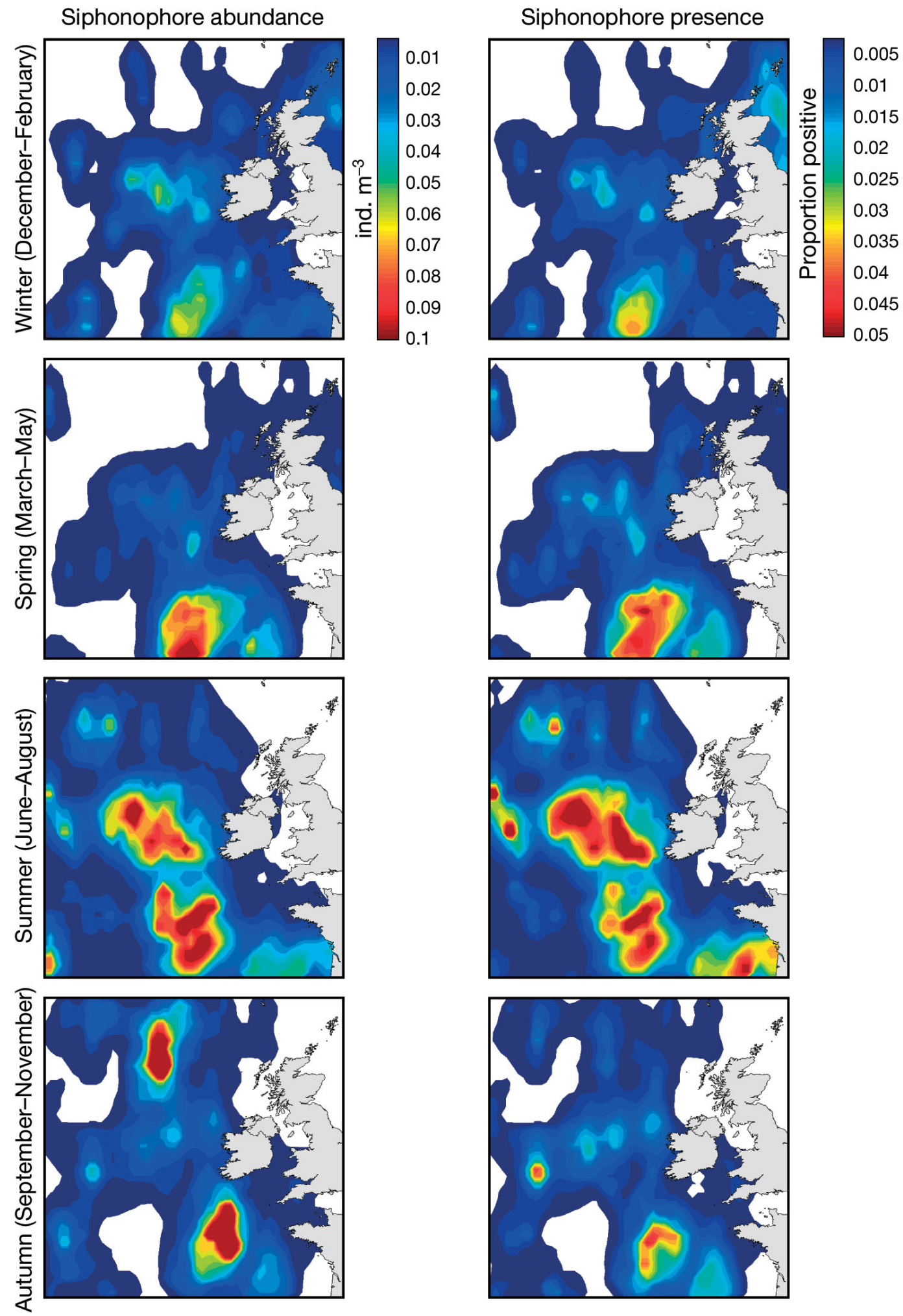

Editorial responsibility: Rory Wilson (Contributing Editor), Swansea, UK 